\title{
Optimization of construction time regulations for large-panel residential buildings
}

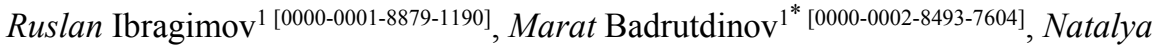 \\ Pugacheva ${ }^{10000-0003-1768-0076]}$, Svetlana Kashina ${ }^{10000-0003-2112-0637]}$, and Reda Farah $^{2}{ }^{[0000-}$ \\ 0002-4390-8428] \\ ${ }^{1}$ Kazan State University of Architecture and Engineering, 420043, Zelenaya st., Kazan, Russia \\ ${ }^{2}$ Academy of Paris 12, boulevard d'Indochine 75019 Paris 47, rue des Écoles 75005 Paris
}

\begin{abstract}
The need to modernize residential construction technologies is an imperative for reducing labour, material, technical, fuel and energy resources. The purpose of the study is to optimize the construction time regulations for the large-panel residential buildings by synchronizing construction flows. The methodological basis contains the principles of climatic zoning for building construction and technical regulation, affecting the particular features of architectural design and the construction schedule. A technique for the combination of maximum allowable types of work under continuous construction arrangement has been developed and coefficient of combination of different types of work for construction flows synchronization has been determined. The practical significance of the study is to improve the process of exterior wall panels installation, provided that an integrated regulation model based on the Spider Project software package is used. The social significance of the study is to make the reduction of the construction time and saving resources possible. The originality of the study is that the combining of different work types during the installation of exterior wall panels of a large-panel residential building has been justified. The need for creation of regional regulations for the construction time has been proved.
\end{abstract}

Keywords: construction of residential buildings, construction time, construction and climatic zoning, technical regulation, combination of types of work.

\section{Introduction}

The relevance of the study is due to the need to modernize the construction technology of residential buildings to reduce labor, logistical, fuel and energy resources [1]. In Russia, the demand for large-panel residential buildings is increasing. The reasons for demand include the following: 1) the cost, which is $50-60 \%$ lower than the monolithic framework house; 2) the speed of construction, since the prefabricated panels do not require additional costs, there is no need to fill the walls, you can immediately glue the wallpaper or paint the surface. In Russia, one of the documents that regulates the

\footnotetext{
${ }^{*}$ Corresponding author: badrutdinovm@gmail.com
} 
construction of a large-panel residential building is the building regulations «Construction time limits and reserve in the construction of facilities, buildings and structures» (in Russian SNiP) [2]. Building regulations are rules and regulations that cover the part of the state standardization system. The building regulations 1.04.03-85 define the construction time, which consists of four stages. The first stage is preparatory, when it is necessary to bring the construction site into proper condition, put on the necessary level. The second stage is underground. At this stage, the base and foundation are being arranged. The third stage is aboveground. At this stage, a constructive system is being assembled, which can be framework or non framework; building is being raised to a certain height using panel plates, columns, pylons, floor slabs and coatings. The fourth stage is finishing. The duration of each stage is set in months (see table 1).

Table 1. Nominal construction time of large-panel residential buildings according to building regulations $1.04 .03-85$, taking into account type series, modification, number of storeys, area (months).

\begin{tabular}{|c|c|c|c|c|c|c|}
\hline \multirow{3}{*}{ Model series } & \multirow{3}{*}{$\begin{array}{l}\text { Modification, number of } \\
\text { storeys, area }\end{array}$} & \multicolumn{5}{|c|}{ Construction time (months) } \\
\hline & & \multirow{2}{*}{ total } & \multicolumn{4}{|c|}{ stages } \\
\hline & & & preparatory & underground & aboveground & finishing \\
\hline $\begin{array}{l}\text { Series ABD- } \\
\quad 9000 \mathrm{~K}\end{array}$ & $\begin{array}{l}\text { ABD-9000K.14 large- } \\
\text { panel, } \\
14 \text { floors. } \\
\text { Total area } 2860.1 \mathrm{~m}^{2}\end{array}$ & 7.3 & 1.0 & 1.5 & 3.3 & 1.5 \\
\hline $\begin{array}{l}\text { Series ABD- } \\
\quad 9000 \mathrm{~K}\end{array}$ & $\begin{array}{c}\text { ABD-9000K.17 large- } \\
\text { panel, } \\
17 \text { floors. } \\
\text { Total area } 2860.1 \mathrm{~m}^{2}\end{array}$ & 7.7 & 1.0 & 1.5 & 3.7 & 1.5 \\
\hline Series 90 & $\begin{array}{l}\text { 90-05 large-panel, } \\
10 \text { floors. } \\
\text { Total area } 1180.8 \mathrm{~m}^{2}\end{array}$ & 5.3 & 1.0 & 1.0 & 2.3 & 1.0 \\
\hline $\begin{array}{l}125 \text { Volga } \\
\text { Tower }\end{array}$ & $\begin{array}{l}125 \text { Volga Tower } \\
\text { large-panel, } \\
16 \text { floors. } \\
\text { Total area } 676 \mathrm{~m}^{2}\end{array}$ & 7.1 & 1.0 & 1.5 & 3.1 & 1.5 \\
\hline Series 83 & $\begin{array}{c}\text { 83-HЧ }(-014,-015,-016, \\
-018,-022(1),-023) \\
\text { large-panel, } \\
10 \text { floors. } \\
\text { Total area } 885.6 \mathrm{~m}^{2}\end{array}$ & 5.2 & 1.0 & 1.0 & 2.2 & 1.0 \\
\hline
\end{tabular}

Table 1 shows that, firstly, the preparatory stage takes one month regardless of the number of floors, the volume of the building and is designed for the use of a single assemble crane. Secondly, the construction season is not taken into account. The duration of the preparatory stage is significantly increased in the winter months. Thus, the nominal and actual durations of large-panel residential buildings construction time do not match (see table 2).

Table 2 shows the difference between the nominal and actual large-panel residential buildings construction time. There are two reasons for this difference.

One of the reasons is the absence of regional regulations for construction time. Russia is a country with different climatic zones. It is important to fully take into account the climatic conditions of the construction area, which are essential for making constructive decisions [3]. The climatic conditions of construction area include the temperature and humidity of the outside air, height of the snow cover, strength of the 
wind, depth of the seasonal soil freezing and location of the groundwater. In construction practice this is manifested in the thickness and material of the building's walls, presence or absence of the foundation hydroprotection, density and variety of roof material, need for deep utilization of engineering communications.

Table 2. Nominal and actual construction time of large-panel residential buildings, taking into account the modification of model series, the number of floors (months).

\begin{tabular}{|c|c|c|c|c|c|}
\hline \multirow[b]{2}{*}{$\begin{array}{l}\text { Model series } \\
\text { modification }\end{array}$} & \multirow[b]{2}{*}{$\begin{array}{c}\text { Total area } \\
\mathrm{m}^{2}\end{array}$} & \multirow[b]{2}{*}{$\begin{array}{l}\text { Number of } \\
\text { floors }\end{array}$} & \multicolumn{2}{|c|}{ Construction time } & \multirow[b]{2}{*}{ Difference } \\
\hline & & & $\begin{array}{l}\text { Nominal } \\
\text { (building } \\
\text { regulations } \\
1.04 .03-85 \text { ) }\end{array}$ & Actual & \\
\hline ABD -9000K.14 & 2860.1 & 14 & 7.3 & 24.0 & +16.7 \\
\hline ABD -9000K.17 & 2860.1 & 17 & 7.7 & 9.0 & +1.3 \\
\hline $90-05$ & 1180.8 & 10 & 5.3 & 5.2 & -0.1 \\
\hline 125 Volga Tower & 676 & 16 & 7.1 & 6.7 & -0.4 \\
\hline \begin{tabular}{|l}
$83-\mathrm{NCH}(-014,-015,-$ \\
$016,-018,-022(1),-023)$
\end{tabular} & 885.6 & 10 & 5.2 & 6.8 & +1.6 \\
\hline
\end{tabular}

In Russia, there are 4 main building climatic zones, which in turn are subdivided into 16 climatic subdistricts, as well as a special northern building climatic zone, including the harshest, least severe and most severe areas [4]. The construction of large-panel residential buildings in all the constituent entities of the Russian Federation is based on model rules regulated by building regulations $1.04 .03-85$. The exception is the city of Moscow, which, as the capital of the Russian Federation, is an independent entity - a city of federal significance. Taking into account the construction climatic zoning in Moscow, regional regulations for the construction of large-panel residential buildings have been adopted [5]. It was found that the average reduction in the construction time in accordance with building regulations 3.2.81-12 and building regulations 1.04.03-85 for large-panel residential buildings was 0.79 months (see table 3 ).

The average reduction in the construction time will be:

$$
\Delta T=-\frac{0,7 \times 2860,1+1,2 \times 1180,8+0,5 \times 676}{2860,1+1180,8+676}=-0,79 \mathrm{mon} .
$$

Table 3 shows that the regional construction regulations (building regulations 3.2.81-12) significantly reduce the construction time of large-panel residential buildings.

Table 3. Large-panel residential buildings construction time comparison according to building regulations 1.04.03-85 and building regulations 3.2.81-12 (months).

\begin{tabular}{|c|c|c|c|c|c|}
\hline \multirow{2}{*}{$\begin{array}{l}\text { Model series } \\
\text { modification }\end{array}$} & \multirow{2}{*}{ Total area, $\mathrm{m}^{2}$} & \multirow{2}{*}{$\begin{array}{c}\text { Number of } \\
\text { storeys }\end{array}$} & \multicolumn{2}{|c|}{ Construction time } & \multirow{2}{*}{ Difference } \\
\hline & & & $\begin{array}{c}\text { building } \\
\text { regulations } \\
1.04 .03-85\end{array}$ & $\begin{array}{c}\text { building } \\
\text { regulations } \\
3.2 .81-12\end{array}$ & \\
\hline ABD-9000K.14 & 2860.1 & 14 & 7.3 & 6.3 & -1.2 \\
\hline $90-05$ & 1180.8 & 10 & 5.3 & 4.6 & -0.7 \\
\hline 125 Volga tower & 676 & 16 & 7.1 & 6.6 & -0.5 \\
\hline
\end{tabular}

Another reason for the difference between the nominal and actual construction time of large-panel residential buildings is the consistent execution of the stages. This significantly increases the construction time [6]. However, if the building is 3 -section or 
more, it is possible to combine the stages, shorten the construction time and apply the flow method.

It is possible to dig the base for the foundation in sections. When the foundation for two sections is brought to the level of 0.000 , and the strength of the concrete reaches 70 $\%$ you can simultaneously assemble the building's first two sections and make the foundation for the third section. When the building reaches the 5 floors level, you can proceed to the finishing works, which makes possible to achieve the maximum allowable reduction in the construction time [7].

The flow method optimizes the construction scheduling. Optimization is possible by combining the stages of construction [8]. If amount of work at each stage is reflected in a percentage, then we get the coefficient for combining various types of work (see table 4).

Table 4. Amount of work and the coefficient of combining various types of work in the construction of large-panel residential buildings.

\begin{tabular}{|c|c|c|}
\hline Stages of construction & Amount of work & Coefficient of combining \\
\hline Preparatory & $100 \%$ & 1 \\
\hline Underground & $60 \%$ & 0.73 \\
\hline Aboveground & $30 \%$ & 0.86 \\
\hline Finishing & $30 \%$ & 0.92 \\
\hline
\end{tabular}

Table 4 makes clear that the amount of work allows combining of the stages. For example, it is possible to build the aboveground part when the foundation is developed by $60 \%$, it is possible to begin the finishing work when the building is assembled to a height of more than $30 \%$. Network schedule for a large-panel residential building construction can be made. Symbols used in the network schedule are presented in Fig. 1.

\section{Symbols}

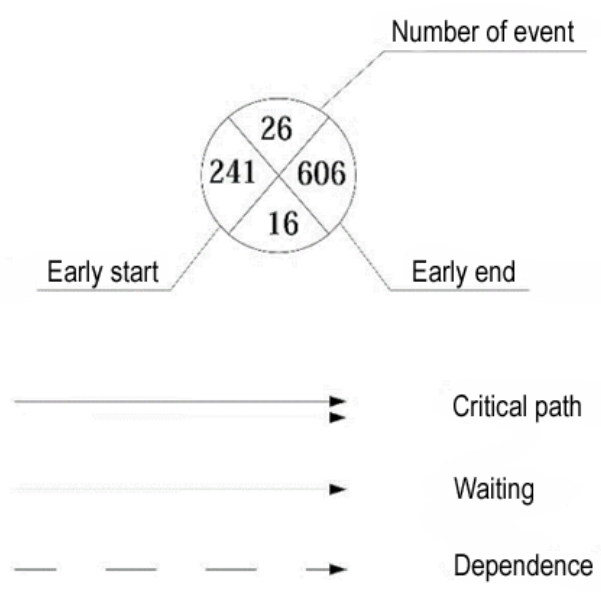

Fig 1. Symbols of the network schedule for a large-panel residential building construction.

Fig. 1 shows that the efficiency of construction process increases of the time spent on completion of work is minimized. Fig. 2 shows the network schedule. 


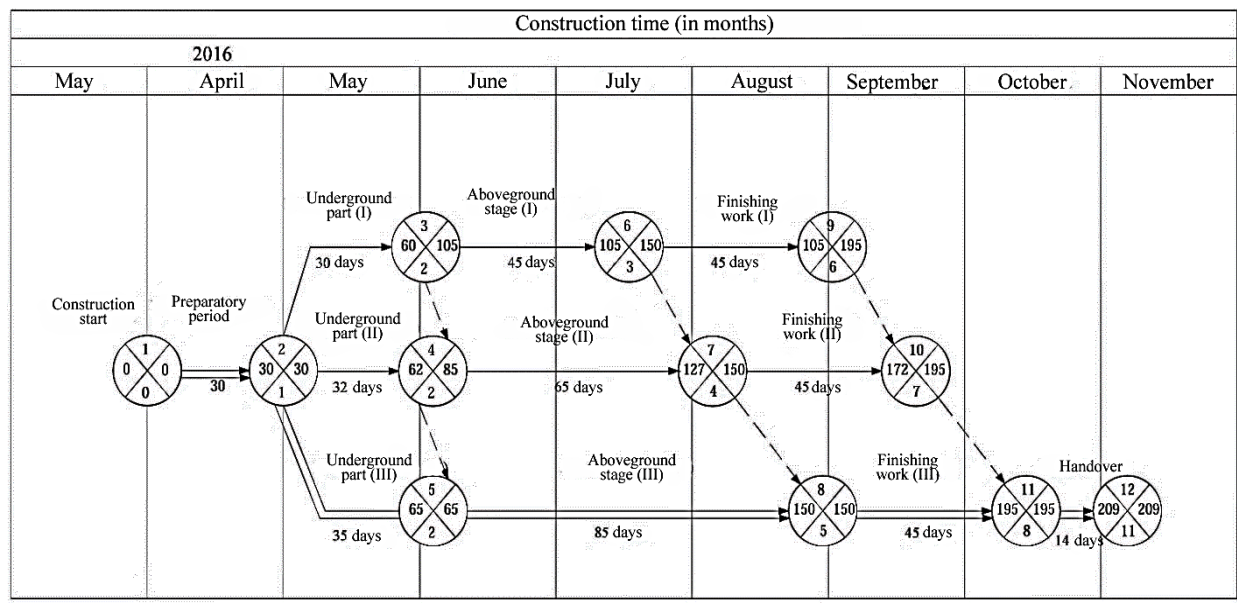

Fig. 2. Network schedule for a large-panel residential building construction.

Fig. 2 shows that the effectiveness of the maximum allowable combination of work types is enhanced if the construction processed is arranged in multiple flows [9]. All of the above highlights the need for the optimization of construction time regulations for large-panel residential buildings, taking into account the climatic zoning for building construction. Reducing the construction time contributes to the development of investment projects that vary in constructive and space-planning solutions, general work arrangement and construction process technologies [10]. The purpose of the study is to optimize the construction time regulations for the large-panel residential buildings by synchronizing construction flows.

\section{Research methodology}

The principles of climatic zoning for building construction and technical regulation were the methodological basis. The principle of climatic zoning for building construction includes the allocation of natural climatic zones, boundaries of which are determined in accordance with the geographical distribution of specific climatic characteristic values that affect the buildings heat balance and the bioclimatic comfort of the built-up area: wind speed and air temperature in winter (January), temperature and humidity in summer (July). Climatic zoning for building construction determines the division of territories into climatic zones, within which certain typological requirements on buildings are applied. These requirements form ideas about the type of building, apartment space-planning solutions, room orientation, entrance node arrangement, construction methods, etc., and in terms of populated places planning they establish requirements for its compactness and pedestrian accessibility for cultural, social and transport services. Based on the principle of climatic zoning for building construction in Russia, the regulations «Building climatology» have been developed, which give an assessment of the background climatic conditions, on the basis of which the architect focuses on the admissibility of variable design solutions, gets an idea of the architectural and town-planning requirements. These regulations do not give architectural and planning recommendations, they focus on what is possible in this climate, to what extent and what is unacceptable. At the same time, a creative analysis of local climatic conditions for taking of an original, expressive, artistically solid and meaningful architectural solution remains withing the architect and city planner 
themselves. Climatic zoning for building construction determines the essence and the content of the services development state regulation in the construction industry [11].

The principle of technical regulation includes the procedure for drafting a timetable for the building construction on the basis of a feasibility study with the maximum possible work combination [12]. To achieve this the following is needed:

1. to study the initial data on objects with similar space-planning and design solutions, areas, number of storeys, estimated cost of work, etc.;

2. to find out the types of work and determine the stages of construction;

3. to determine the amount of work at each stage;

4. to identify the possibilities of maximal types of work combination carried out by the flow method in two or three shifts and determine the duration of each stage;

5. to determine the construction time by interpolation and extrapolation methods, taking into account the level of construction production arrangement, the use of modern technologies, the use of new building materials, parts, structures, and the number of the tower crane shifts (the interpolation method is used if the features of the object correspond to the typical ones presented in building regulations 1.04.03-85) (the extrapolation method is used if the features of the object do not correspond to the typical ones);

6. to draft a network schedule of works, reflecting the interrelations between the construction participants and establishing the timelines for issuing documentation, installation and commissioning works performed by specialized organizations;

7. to draft a work timetable by year, month, day with the distribution of capital investments;

8. to develop the flow charts for specific types of work.

In the process of research, the following methods were used: analysis of the regulation models for the construction time of residential houses [13]; simulation modeling of technological and organizational construction processes [14]; system analysis [15]; methods of computational justification [16], including the use of computer-aided design software packages Microsoft Project and Spider Project [17].

\section{Results}

The main result of the study is the technique of combination of maximum allowable types of work in the process of installing exterior wall panels of a large-panel residential building under continuous construction arrangement in two or three shifts. The technique includes several sections: 1) arrangement and technology of carrying out the work; 2) quality assurance; 3 ) safety technique.

\subsection{Arrangement and technology of carrying out the work}

The installation of exterior wall panels can be started upon completion of the underground construction phase (the joints in the floor panels are embedded; the installation horizon is defined; the alignment axes and installation marks are made; the elevator shaft unit is mounted; engineers are familiar with the technology of work and trained to the safe methods of work) and the required strength of concrete in 2 sections is set (provided that the house consists of 3 sections). Thus, two stages are combined underground and aboveground. This increases the need for machines and mechanisms [18].

The installation of exterior wall panels is recommended to be carried out with the KB-581-00 tower crane with a lifting capacity of 10 tons with a building height of up to $50 \mathrm{~m}$. Location of the tower crane and the distance from the crane tracks to the building 
is determined depending on the building's space planning solution and the brand of the crane (see Fig. 5).

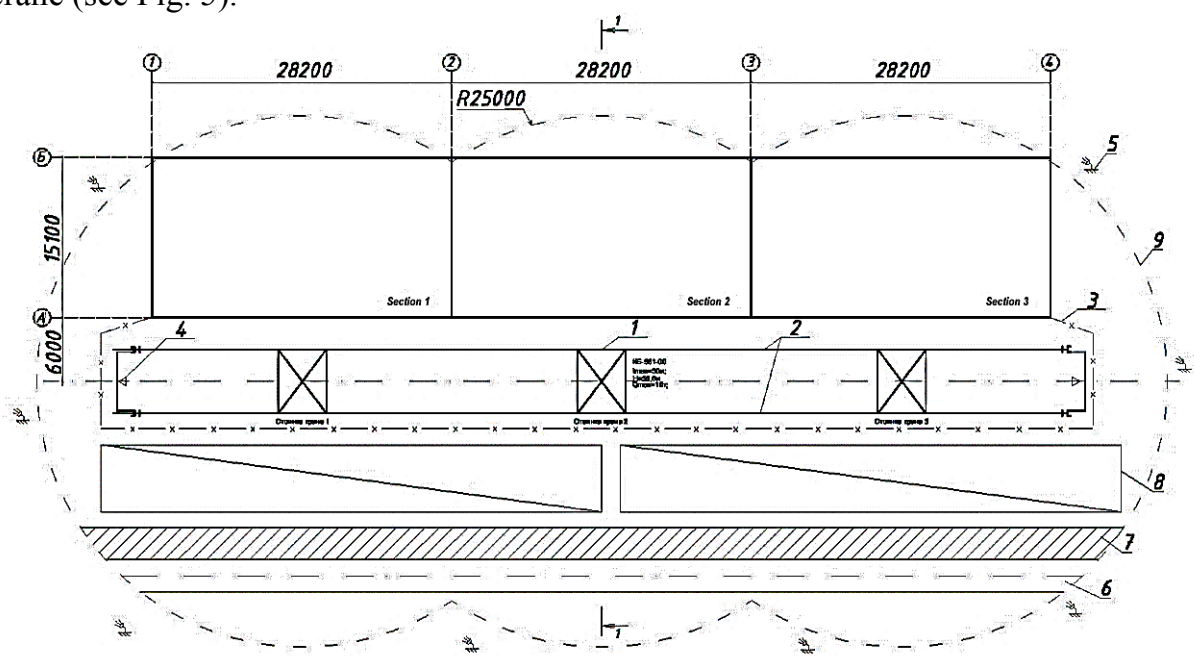

Fig. 3. The layout of the tower crane KB-581-00: 1 - tower crane; 2 - crane runway; 3 - crane runway fence; 4 - ground loop; 5 - spotlights; 6 - temporary road; 7 - a platform for unloading vehicles and for receiving mortar and concrete; 8 - temporary open storage area; 9 - crane operation limit.

Fig. 3 shows that the maximum distance from the crane movement axis to the wall is determined by its technical specifications, the minimum - by safety measures. The cross section of the tower crane with the attachment to the building being assembled is shown in Fig. 4.

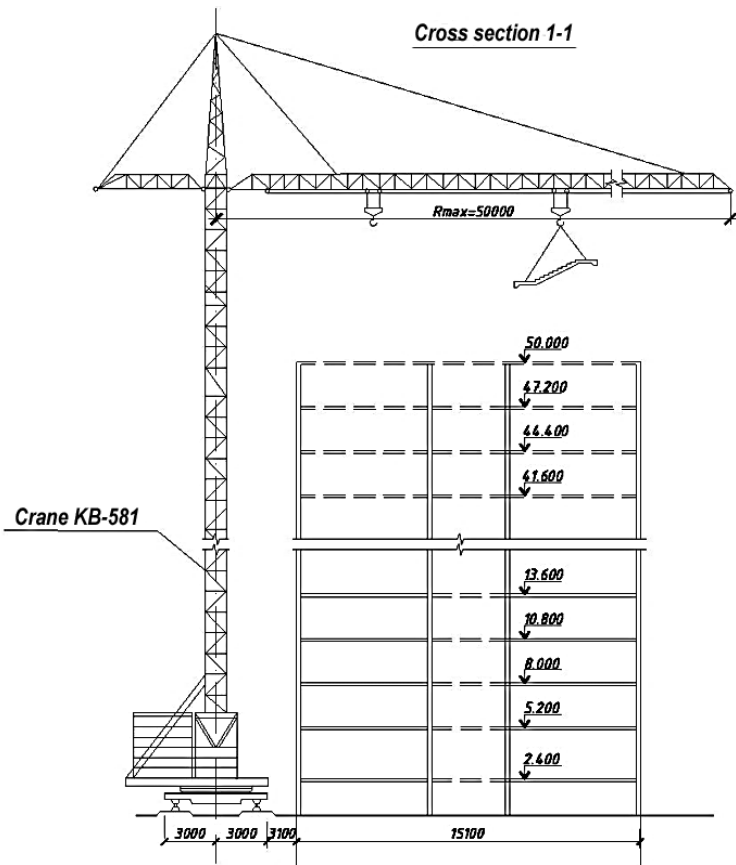

(A)

(B)

Fig. 4. The cross section of the tower crane with the attachment to the building. 
Fig. 4 shows that the attachment of the tower crane to the building is associated with the quality control of work and safety techniques during the installation of exterior wall panels.

Delivery of exterior wall panels is carried out by panel semi-trailers in a vertical or slightly inclined position (at an angle of not more than $12^{\circ}$ to the vertical). Transporting vehicles must have the necessary equipment to ensure a stable position of the exterior wall panels during transportation and to protect them from damage. External wall panels are delivered to the construction site with a set of metal fittings and linings, which are transported in closed containers.

Installation of exterior wall panels is produced from vehicles. The slinging of the panels is carried out using a universal beam traverse or universal four branch traverse, provided that the vertical angle of the sling should not exceed $15^{\circ}$ (Fig. 5).
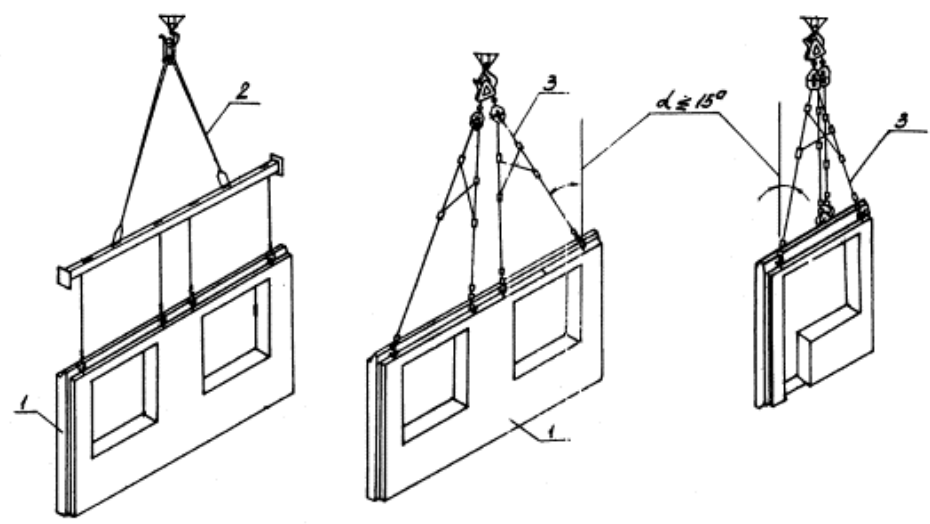

Fig. 5. Installation of exterior wall panels: 1 - mounted exterior wall panel; 2 - universal beam traverse; 3 - universal self-balancing traverse.

Fig. 5 shows that the installation of exterior wall panels is carried out by divisions (one block section is assigned for the division) and performed in a certain technological sequence. Installation of exterior wall panels should be performed by the principle of «towards the crane», in which the panels furthest from the crane are installed first.

When installing exterior wall panels, the following procedure order should be executed: installation of exterior wall panels; construction of air insulation pasting; installation of a heat-insulating insert; anchoring wall panels in designed position (after their installation); embedment of vertical joints of exterior wall panels (after laying the floor slabs of the installed floor).

Before mounting exterior wall panels, the supporting surface is aligned with beacon linings, the top of the beacons are installed in accordance with the mounting horizon, the beacon linings made of hardwood or cement mortar are placed under each panel two beacons at a distance of $0.2-0.3 \mathrm{~m}$ from the ends of the panel. Deviations of beacon marks from to the mounting horizon should not exceed $\pm 5 \mathrm{~mm}$.

Wall panels are placed on a layer of cement mortar that is spread $5 \mathrm{~mm}$ above the beacon level. Mortar's brand is specified in the project.

The installation of external wall panels is carried out as follows: 1) the installers take the panel raised by a crane to a height of $0.3-0.4 \mathrm{~m}$ from the ceiling; 2 ) they make the alignment of its position in the transverse and in the longitudinal direction; 3 ) the panel is installed on the mortar bed prepared for it.

The panel is not allowed to move (straightening) on the mortar after installation. If there is a deviation from the designed position, the panel must be raised by a crane, its bottom must be cleared of the mortar, after which it must be installed on the fresh 
mortar again. The application of the mortar, which process of setting has already started, as well as the restoration of its plasticity by adding water is not allowed. Temporary anchorage of exterior wall panels is implemented by shortened or basic struts, at the rate of two trays per panel (see Fig. 6).

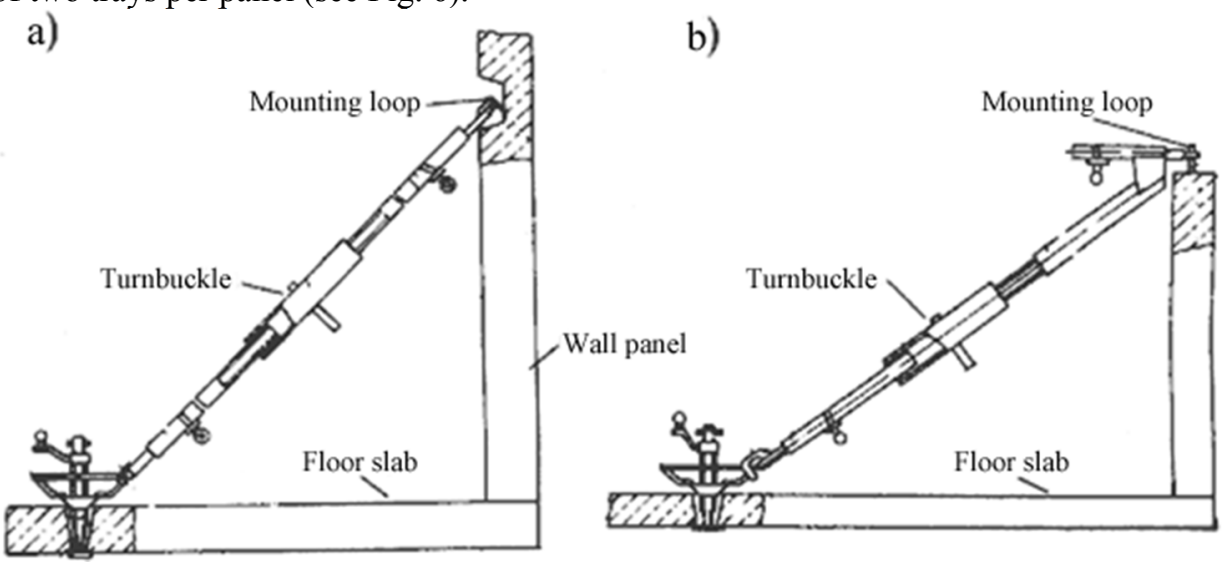

Fig. 6. Scheme of wall panels temporary anchorage with struts: $a$ - short strut; $b$ - long strut.

Fig. 6 shows that the lower end of the strut is attached to the anchor device installed in the technological opening of the floor plate, the upper end - to the anchor or lifting loop of the outer wall panel.

Anchoring of the outer wall panels is carried out after inner wall panels installation in the designed position and their temporary anchoring with struts. The mounting brackets are mounted in the following sequence: brackets connecting the anchor loops of the outer wall panels with the anchor loop of the inner wall panel are inserted into the holes of the diaphragms from above, and the bracket connecting the anchor loops of the outer wall panels between them from below, after which the ends of this bracket are bent using the bending conductor. In the lower anchor loop of the upper well and the anchor loop of the lower well three galvanized brackets are being installed, connected by triangle point welding.

Welding of metal joints of outer and inner wall panels in loggia should be carried out in accordance with the instructions.

The embedment of the external walls vertical joints must be performed after laying the floor slabs during the installation of one horizontal row and should be done with heavy concrete on small aggregate of class B15 (M200).

The filling of the joints with concrete is carried out with using a vibro-bunker, the concrete is compacted with a deep vibrator [19].

The accuracy of the panel installation in vertical axis is checked by installers with a rack bar plumb on two faces: the side and open end, and in horizontal axis by the leveling tool. Special templates are used on the panel position alignment (see Fig. 7). 
a)

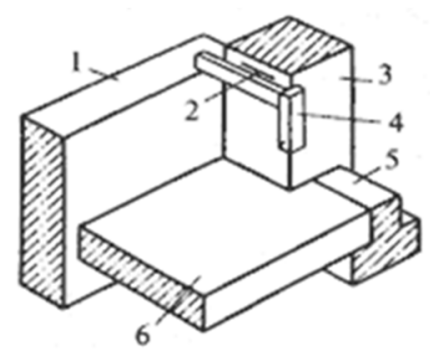

c)

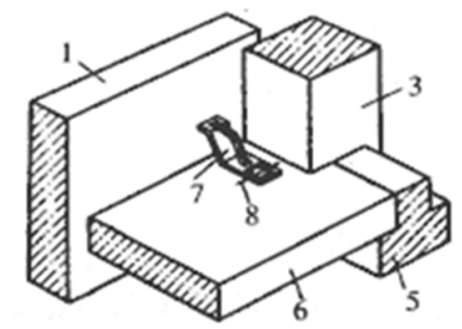

b)
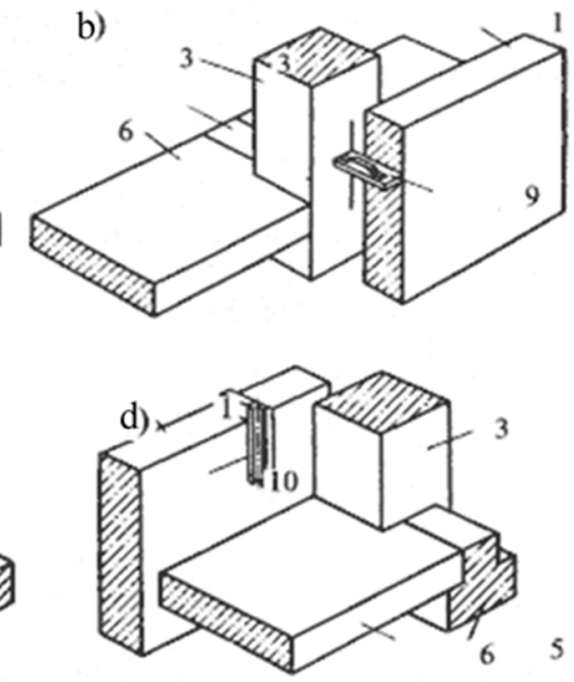

Fig. 7. Methods of the wall panel position alignment: $a$ - at height; $b$ - in the transverse direction; $\mathrm{c}$ - in the longitudinal direction; $\mathrm{d}$ - vertically. 1 - panel; 2 - mark on the column; 3 - column; 4 , 8 -templates; 5 - bolt; 6 - floor plate; 7 - mark; 9 - template gauge; 10 - plumb gauge.

Fig. 7 shows that there are several ways to align the position of the wall panel. This highlights the need to control the quality of work.

\subsection{Quality assurance}

Quality assurance for installation of exterior wall panels includes the following: input quality assurance of structures and materials that are used; operational quality assurance of the work performed; initial inspection of the work performed [20]. Input quality assurance of structures at the construction site is made by engineering and technical staff of the organization that does the assembly. Exterior wall panels must have a passport, clearly visible marking and stamp of the factory with the date of manufacture. The compliance of the passport data with the design data is being checked and an external inspection and measurement of the structures is carried out. External wall panels arriving at the construction site must comply with the requirements of the state standard and working drafts. Initial inspection of the assembled exterior wall panels is carried out in the process of floor-by-floor acceptance of the assembled structures on a division. When accepting the work, the installation and welding work logs, the monolithing of vertical joints logs, the documents of laboratory analyzes and tests during joints welding and monolithing, acts of hidden works examination (welding, insulating) are presented. It's been determined that the optimization of the quality assurance process is enhanced when the educational cluster for training the specialists is established [21].

\subsection{Safety technique}

Works carried out on the installation of exterior wall panels should be performed in compliance with the requirements of safety in construction [22]. It's been determined that the effectiveness of compliance with the safety technique is enhanced when the specialists are being trained using the virtual construction site [23]. All workers at the 
construction site must be provided with personal protective equipment, clothing and footwear. Cranes, traverses, slings and other lifting devices before use must be inspected and tested, and then an appropriate act is drawn up. Typical slinging patterns of basic structures should be placed on the assembly crane. The hooks of the crane and lifting devices must have working locking devices. It is necessary that all lifting devices have passports and an accession number.

Before starting, as well as during the work, rigging and mounting devices (slings, traverses, struts, clamps), inventory and containers must be inspected.

Loading and unloading operations are carried out under the guidance of a master or foreman, who is obliged to monitor the correct placement of materials in the warehouse, the working condition of the lifting and transport equipment and accessories.

When unloading structures from vehicles, the driver must exit the cab. Moving cargo over it is not allowed.

External wall panels should be assembled in the technological sequence provided for in the flow chart.

When installing exterior wall panels, one element should be successively attached to another. Do not allow the panel to be rolled up from the top between two previously mounted elements, with the exception of the last closing panel. This element is installed under the supervision of a foreman or master.

When installing exterior wall panels, it is necessary to observe the following installation rules: before lifting the panel, check the sling reliability, quality of elements, elements with defects should not be mounted; do not allow the crane to lift the panels pressed by other elements or frozen to the ground; move structures and other goods in the horizontal direction at a height of at least $0.5 \mathrm{~m}$ and at a distance of at least $1 \mathrm{~m}$ from other structures; do not allow the transfer of the structures with a crane over the workplace of installers, as well as over the division where other construction works are being carried out; bring the elements to the installation site with a crane from the outside of the building; take the supplied element only when it is $0.2-0.3 \mathrm{~m}$ from the installation site; when taking an element, installers must not be between it and the edge of a slab or other structure.

Temporary anchors can be removed only after permanent anchoring of the elements. Anchorage of the mounted panels, releasing them from the slings, installation of the brackets, as well as sealing of the joints should be made from mobile scaffolding. It is forbidden to use ladders for these purposes.

It is not allowed to work and be in the lower floors of the building on those divisions where structures on the floors are mounted, as well as in the zone of movement of elements by cranes.

It is not allowed to perform installation work at a height in open areas with a wind speed of $15 \mathrm{~m} / \mathrm{s}$ and more, with icy conditions, thunderstorms or fog, eliminating visibility within the work front. Work on the movement and installation of vertical panels and similar structures with high windage should be stopped at a wind speed of 10 $\mathrm{m} / \mathrm{s}$ and more.

The admission to the production of welding should be carried out after reading the technical documentation and briefing on the operation of equipment and labor protection. Welders working places should be separated from adjacent jobs and passages with fireproof materials (screens, shields) with a height of at least $1.8 \mathrm{~m}$. It is forbidden to combine welding work and laying of the insulating liner on one workplace. It is prohibited to place easily combustible materials within a radius of $10 \mathrm{~m}$ from the place of electric welding. After the completion of welding works, it is necessary to check the workplace in order to identify and eliminate hidden fire sources that may cause a fire. 
When performing air and heat insulation and embedding the joints, the following safety precautions should be observed: adhesive pastes used as an undercoat for sticking air protection tape are considered to be flammable, explosive and toxic materials.

\section{Discussion}

The problem of optimizing the regulations of the building construction time attracts increasing attention of scientists. The subject of many studies is the of the construction time rationing calculation. To calculate the construction time rationing, use of the Microsoft Project and Spider Project software packages is justified [24]. These software packages provide an opportunity to present scheduling with the possible job combinations, which significantly affects the construction time indicator. Microsoft Project has the ability to structure the construction process by highlighting the stages and their constituent periods; goals and objectives; to draft the technological processes schedule; allocate labor and material resources (see Fig. 8).

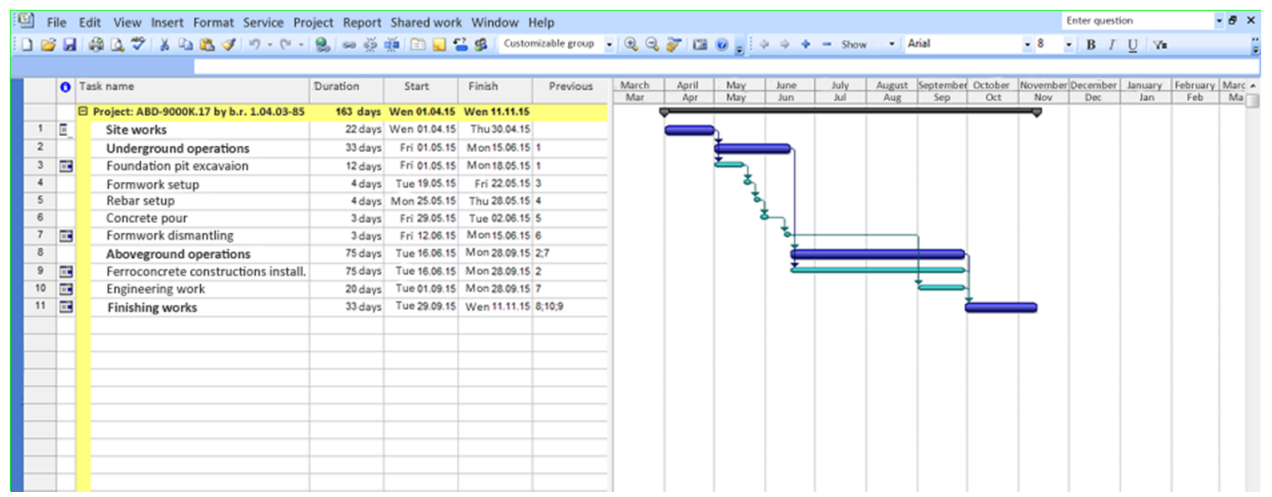

Fig. 8. Construction time of a large-panel residential building ABD-9000K.17 series according to Microsoft Project software package.

Fig. 8 shows that the Microsoft Project helps in development of schedules, allocation of resources by task, analysis of the amount of work. It allows decomposing the process into components [25]. However, each component is considered as independent, which consistently follows after the previous one.

The Spider Project was developed in Russia and is designed to use innovative technologies in project management [26]. It allows quick management of cost, resources, and deadlines for the work (see Fig. 9).

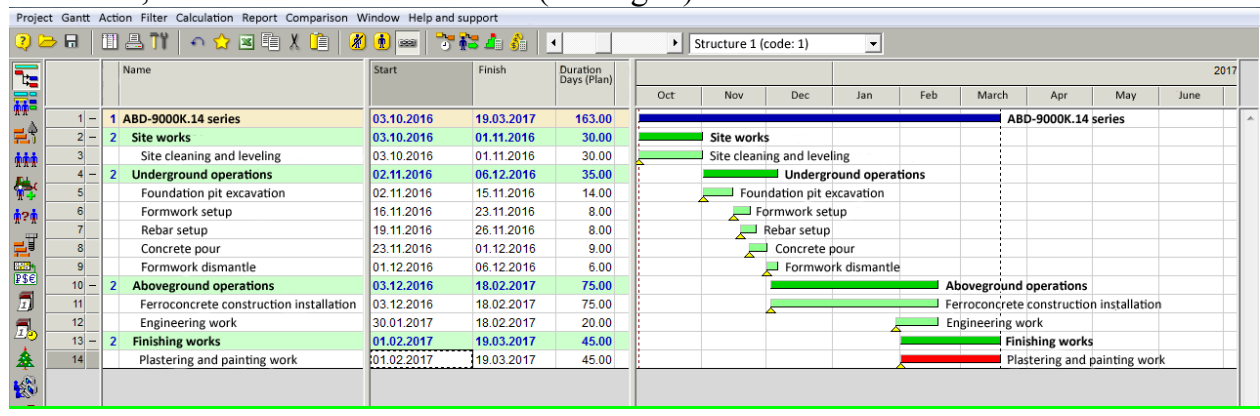

Fig. 9. Construction time of a large-panel residential building ABD-9000K.17 series according to Spider Project software package. 
Fig. 9 shows that the Spider Project allows to create not only a schedule, but also to determine the number of working days for each workload. The first version of the Spider Project was released in late 1992. Since then it was under the continuous development, the features and needs of the Russian market were taken into account in the process of enhancing of its functionality. Plans composed by the Spider Project generally have a shorter duration and therefore cost less than plans composed using Microsoft Project. It allows to automatically determine resources, number of hierarchical structures of work; to create and use databases, including regulatory costs and materials costs per unit volume; to develop an unlimited number of project versions; to identify risks; to calculate trends of success rates; to simulate not only costs, but also revenues; to organize an accounting system that allows not only to adjust the remaining durations and workloads, but also to receive reports on the project execution in any perspective and for any period of time; to draft a flowchart as a compact and visual way to display the project schedule.

We compared construction time of a large-panel residential building on the example of ABD-9000K.14 using Microsoft Project and Spider Project. Construction time comparison revealed slight differences (see table 5).

Table 5. Comparison of the construction time for a large-panel residential building on the example of ABD-9000K.14 using Microsoft Project and Spider Project software tools (months).

\begin{tabular}{|c|c|c|c|c|c|}
\hline \multirow{2}{*}{ Series modification } & \multicolumn{5}{|c|}{ Construction time } \\
\cline { 2 - 6 } & $\begin{array}{c}\text { building } \\
\text { regulations } \\
1.04 .03-85\end{array}$ & $\begin{array}{c}\text { building } \\
\text { regulations } \\
3.2 .81-12\end{array}$ & Actual time & $\begin{array}{c}\text { Microsoft } \\
\text { Project }\end{array}$ & $\begin{array}{c}\text { Spider } \\
\text { Project }\end{array}$ \\
\hline ABD-9000K.14 & 7.7 & 7.7 & 9.0 & 5.8 & 5.7 \\
\hline
\end{tabular}

Table 5 shows that the difference in construction time determined on the basis of the Microsoft Project and Spider Project software tools is only 0.1 months. However, for the construction industry it is a lot, as it involves machinery and equipment rental, materials consumption and wages. At the same time the construction time in Microsoft Project and Spider Project is significantly lower than deadlines determined by building regulations 1.04.03-85, building regulations 3.2.81-12 and actual time. For example, if you compare the construction time for building regulations 1.04.03-85 with the one determined by Spider Project, the difference will be 2,0 months.

Thus, the optimization of construction time rationing for large-panel residential buildings in scientific literature and construction practice involves the use of the Microsoft Project and Spider software packages. However, the timetable for the construction and installation works is influenced by the climatic zoning for building construction and the possibility of combining the maximum types of work performed by the flow method in two or three shifts [27]. This is what made our research relevant.

\section{Conclusions}

A technique for the combination of maximum allowable types of work under continuous construction arrangement is due to the lack of regional regulations for the construction duration and its rationing, based on the sequential execution of stages, as well as the introduction of digital technologies in the construction industry [28]. The development of this technique is one of the optimization components of the large-panel residential buildings construction time rationing, as well as the enhancement of construction materials quality [29]. The methodological basis contains the principles of climatic zoning for building construction and technical regulation, affecting the particular 
features of the architectural design, the construction schedule drafting, construction services innovative development and regional socio-economic policy improvement [30]. The main results of the study consist in the development of a technique for the maximum allowable combination of types of work under the continuous construction process arrangement. The significance of the results obtained is that the developed technique allows establishing the relationships between the work arrangement and technology, quality assurance and safety technique in the process of a large-panel residential building's exterior wall panel installation. The work arrangement effectiveness and technology performance is enhanced if the coefficient of combining of different types of work is determined in order to synchronize the construction flows. The effectiveness of quality assurance is increased with the development of multi-stage control system, including input quality assurance of structures and materials that are used; operational quality assurance of work that is performed and its initial inspection. Safety technique relevancy is increased when the maximum allowable combination of types of work carried out by the flow method in two shifts. Improvement of the exterior wall panels installation process is achieved with the use of an integrated rationing model in the Spider Project software package. The correlation of the work organization and technology, quality assurance and safety technique is nonlinear. Materials of this article may be useful for university teachers who train engineers; specialists in design, construction and installation work organizations.

\section{References}

1. B. N. Porfiryev, A. A. Shirov, M. N. Uzyakov, M. S. Gusev, and I. N. Shokin, Stud. Russ. Econ. Dev., 31 (2020) DOI: 10.1134/S1075700720030132

2. SNiP 1.04.03-85 Normy prodolzhitel'nosti stroitel'stva i zadela $\mathrm{v}$ stroitel'stve predpriyatiy zdaniy i sooruzheniy chast' I 2019 [Building regulations 1.04.03-85 Standards for the construction time and foundation in the construction of enterprises, buildings and structures part one 2019] URL: sniprf.ru/razdel-1/1-04-03-85-part0101 (Last accessed: 30.03.2021)

3. A. N. Kozlov, Project Management, 44 (2018) URL: pmmagazine.ru/editions/1-442018/ (Last accessed: 30.03.2021)

4. SP 131.13330.2012 Stroitel'naya klimatologiya aktualizirovannaya redaktsiya SNiP 23-01-99* [Code of rules 131.13330.2012 Construction climatology updated edition of Building regulations 23-01-99*] URL: sniprf.ru/sp131-13330-2012 (Last accessed: 30.03 .2021 )

5. Rekomendatsii po opredeleniyu norm prodolzhitel'nosti stroitel'stva zdaniy i sooruzheniy, stroitel'stvo kotorykh osushchestvlyayetsya s privlecheniyem sredstv byudzheta goroda Moskvy [Recommendations for determining the construction time regulation of buildings and structures, the construction of which is carried out with the involvement of funds from the budget of the city of Moscow] URL: docs.cntd.ru/document/537930021 (Last accessed: 30.03.2021)

6. D. A. Brady, P. Tzortzopoulos, J. Rooke, C. T. Formoso, A. Tezel, Eng. Constr. Archit. Manag., 25 (2018) DOI: 10.1108/ECAM-07-2017-0122

7. R. A. Ibragimov, E. V. Korolev, T. R. Deberdeev, V. V. Leksin, Struct. Concr. 20 (2019) DOI: 10.1002/suco.201800008

8. R. Edirisinghe, Eng. Constr. Archit. Manag., 26 (2019) DOI: 10.1108/ECAM-042017-0066

9. X. L. Gan, R. D. Chang, C. Langston, T. Wen, Eng. Constr. Archit. Manag., 26 (2019) DOI: 10.1108/ECAM-05-2018-0198 
10. V. A. Malahov, Project Management, 45 (2018) URL: pmmagazine.ru/editions/245-2018/ (Last accessed: 30.03.2021)

11. V. G. Ivanov, S. V. Barabanova, R. V. Shagieva, N. M. Chikisheva, A. N. Lunev, N. V. Volkova, K. R. Nabiullina, E. V. Spirina, Int. Rev. Manag. Mark. 6, (2016)

12. N. Pugacheva, M. Badrutdinov, S. Kashina, L. Yarullina, R. Farah, T. Kirillova, A. Lunev, IOP Conf. Ser. Mater. Sci. Eng. (2020) DOI: 10.1088/1757899X/960/2/022042

13. D. Imaykin, R. Ibragimov, IOP Conf. Ser. Mater. Sci. Eng. (2020) DOI: 10.1088/1757-899X/890/1/012126

14. B. Abdal Noor, S. Yi, Constr. Innov. 18 (2018) DOI: 10.1108/CI-05-2017-0040

15. J. M. Savolainen, A. Saari, A. Männistö, K. Kähkonen, J. Eng. Des. Technol. 16 (2018) DOI: 10.1108/JEDT-09-2017-0091

16. J. P. Spillane, L. O. Oyedele, Constr. Innov. 17 (2017) DOI: 10.1108/CI-11-20150063

17. Project management templates URL: www.method123.com/ (Last accessed: 30.03.2021)

18. American society for quality URL: asq.org/ (Last accessed: 30.03.20211)

19. R. A. Ibragimov, E. V. Korolev, T. R. Deberdeev, V. V. Leksin, Struct. Concr., 20 (2019) DOI: $10.1002 /$ suco.201800008

20. N. Pugacheva, T. Kirillova, O. Kirillova, A. Luchinina, I. Korolyuk, A. Lunev, Int. J. Emerg. Technol. Learn., 15 (2020)

21. A. N. Lunev, R. S. Safin, E. A. Korchagin, D. K. Sharafutdinov, T. V. Suchkova, L. V. Kurzaeva, S. R. Nikishina, N. A. Kuznetsova, Int. Rev. Manag. Mark., 6 (2016)

22. A. Pedro, Q. T. Le, C. S. Park, J. Prof. Issues Eng. Educ. Pract., 142, 04015011 (2016)

23. I. Terentyeva, A. Lunev, S. Kashina, L. Sadrieva, I. Korolyuk, N. Pugacheva, Int. J. Emerg. Technol. Learn., 15 (2020) DOI: 10.3991/ijet.v15i13.14655

24. Microsoft project URL: products.office.com/ru-ru/project/project-and-portfoliomanagement-software (Last accessed: 30.03.2021)

25. Spider project URL: www.spiderproject.com/ru/ (Last accessed: 30.03.2021)

26. I. Mirsayapov, I. Koroleva, in Procedia Eng. (2016)

27. R. K. Mukhametrakhimov, L. V. Lukmanova, IOP Conf. Ser. Earth Environ. Sci. (2017) DOI: 10.1088/1755-1315/90/1/012112

28. V. L. Badenko, N. S. Bolshakov, E. B. Tishchenko, A. A. Fedotov, A. C. Celani, V. K. Yadykin, Mag. of Civil Eng., 101 (2020) DOI: 10.34910/MCE.101.14

29. A. Khuzin, R. Ibragimov, J. Build. Eng., 35, 102030 (2021) DOI: 10.1016/j.jobe.2020.102030

30. A. S. Pugacheva, V. P. Filippova, A. Y. Kon, L. B. Dorzhieva, I. S. Silchenok, N. B. Pugacheva, A. N. Lunev, A. A. Mustafina, Int. Rev. Manag. Mark., 6 (2016) 